\title{
Increasing Cultural Competence in Support of Indigenous-Led Evaluation: A Necessary Step toward Indigenous-Led Evaluation
}

\author{
Nan Wehipeihana \\ Research Evaluation Consultancy Limited
}

\begin{abstract}
This paper builds on a keynote paper presented at the 2018 Canadian Evaluation Society annual conference by Nan Wehipeihana, an Indigenous (Māori) evaluator from Aotearoa New Zealand. Nan defines Indigenous evaluation as evaluation that is led by Indigenous peoples; has clear benefits for Indigenous peoples; has Indigenous people comprising most of the evaluation team; is responsive to tribal and community contexts; and is guided and underpinned by Indigenous principles, practices, and knowledge. She argues for Indigenous led as a key criterion for Indigenous evaluation, with no assumed or automatic role for non-Indigenous peoples unless by invitation. She outlines a range of tactics to support the development of Indigenous evaluators and Indigenous evaluation and presents a model for non-Indigenous evaluators to assess their practice and explore how power is shared or not shared in evaluation with Indigenous peoples, as a necessary precursor to increasing control of evaluation by Indigenous peoples.
\end{abstract}

Keywords: control, culturally responsive evaluation, decision making, Indigenous evaluation, Indigenous-led, Kaupapa Māori, power

Résumé : Cet article vient compléter la conférence invitée de Nan Wehipeihana, une évaluatrice autochtone (māori) d'Aotearoa en Nouvelle-Zélande, lors du Congrès annuel de la Société canadienne dévaluation en 2018. Mme Wehipeihana définit l'évaluation autochtone comme une évaluation menée par des personnes autochtones; qui présente des avantages clairs pour les peuples autochtones; dont l'équipe d'évaluation est surtout composée de personnes autochtones; qui est consciente des contextes communautaires et tribaux; et qui est orientée par des principes, des pratiques et des connaissances autochtones. Elle soutient que l'évaluation autochtone devrait être menée par des Autochtones, sans rôles présumés ou automatiques pour les personnes non autochtones à moins quelles ne soient invitées à y participer. Elle décrit toute une gamme de tactiques visant à appuyer le développement des évaluateurs et des évaluatrices autochtones et de l'évaluation autochtone. Elle présente aussi un modèle permettant aux évaluateurs et aux évaluatrices non autochtones dévaluer leur pratique et d'explorer la manière dont le pouvoir est partagé ou non, en évaluation,

Corresponding author: Nan Wehipeihana, P.O. Box 6545, Wellington 6141, New Zealand; nan.wehipeihana@gmail.com, 
avec les peuples autochtones, en tant que préalable nécessaire à l'augmentation du contrôle exercé sur l'évaluation par les peuples autochtones.

Mots clé : contrôle, évaluation adaptée à la culture, prise de décision, évaluation autochtone, leadership autochtone, Kaupapa Māori, pouvoir

Ko Taraura te pae maunga.

Ko Ohau tōku awa.

Ko Tukorehe tōku marae.

Ko Ngāti Tukorehe te iwi i te taha o tōku matua.

Ko Ngāti Porou me Te-Whānau-ā-Apanui ōku iwi i te taha ūkaipō.

Tuku mihi ōku maunga kingā maunga o tènei rohe, o tènei whenua.

Tuku mihi ōku awa, òku moana ki ngà awa me ngà moana o tēnei rohe, o tēnei whenua.

Ki te tangata whenua o tēnei whenua, kei te mihi.

Ki te atua i runga rawa, nāna i homai nāna itango, kei te mihi.

Ingā mate kua rūpeke atu ki te pō, haere haere oki oki atu.

Ko Ngahorihori (Nan) Wehipeihana ahau.

Tuku mihi ki a koutou katoa, no ngā haue whā, tènā koutou katoa.
Tararua are the mountain ranges

Ohau is my river

Tukorehe is my traditional meeting place

Ngäti Tukorehe is my tribe on my father's side.

Ngāti Porou and Te-Whānau-ä-Apanui are my tribes on my mother's side.

My mountains greet the mountains of this region, of this land

$M y$ rivers and my oceans greet

the rivers and oceans of this region, of this land.

l acknowledge the traditional people of this land.

To the creator of all things, who gives and takes all things, I greet you.

To the people who have gone before us, I acknowledge you.

I am Ngahorihori (Nan) Wehipeihana

And to all gathered here today, from the four winds, I greet you.

I start my presentation today with a mihimihi (a traditional introduction), as I start every presentation, whether at home in Aotearoa New Zealand or as a visitor on another people's land. I do this by identifying my connections to places of significance to my people, our mountains, rivers, and marae (traditional meeting places) and I acknowledge my relationships to people both past and present. I also greet the traditional custodians of this land, attesting to my visitor status.

My mihimihi affirms my whakapapa (genealogy and identity) and my links to the land, to the natural environment, and to ancestors, the spirits, and the cosmos (Marsden \& Royal, 2003). It reminds us of our connectedness to people and to place (Henare, 1988; LaFrance \& Nichols, 2010), that we all connect to a spiritual source and exist in a web of reciprocity with each other and all creation (Spiller \& Stockdale, 2013).

Entering Māori communities, like many Indigenous communities, typically involves other rituals of encounter such as pōwhiri (formal welcome), whaikōreoro 
(speeches), and karakia (ritual chants or prayer). Collectively, these cultural protocols signal a movement from the contemporary world dominated mainly by Western practices into a Māori world where Māori values and norms hold sway; and they help to prepare and settle us for the context in which we will be working (Wehipeihana \& McKegg, 2018).

In this presentation, I define Indigenous evaluation, outline the rationale for Indigenous-led, put forward a strategy to support Indigenous-led evaluation, and share a model (Wehipeihana, 2013) for non-Indigenous evaluators to reflect on their positioning and ways of working to reveal the power dynamics that are a barrier to Indigenous evaluation being led by Indigenous peoples.

\section{DEFINING INDIGENOUS EVALUATION}

When I think about Indigenous evaluation (or in my case Kaupapa Māori evaluation), it is about evaluation by Indigenous, for Indigenous, with Indigenous, and as Indigenous; and where there is no assumed role for non-Indigenous people, unless by invitation. In Aotearoa New Zealand, "By Māori, for Māori, with Māori" (Cram, 2016; Cram, Chilisa, \& Mertens, 2013) has variously been part of the research and evaluation agenda since the 1980s (and more recently "as Māori": Durie, 2001; Wehipeihana, McKegg, Thompson, \& Pipi, 2015) (see Table 1).

\section{INDIGENOUS SELF-DETERMINATION IS FUNDAMENTAL}

Kaupapa Māori evaluation has its foundations in the principle of Tino Rangatiratanga (chiefly leadership) which appears in the Māori version of the Treaty of Waitangi

Table 1. Core determinants of Māori and Indigenous evaluation

\begin{tabular}{|c|c|}
\hline $\begin{array}{l}\text { By Māori: } \\
\text { (by Indigenous) }\end{array}$ & $\begin{array}{l}\text { is about evaluation led by Māori and where Māori have the } \\
\text { overall authority and power to make decisions about the } \\
\text { evaluation design, methods, evaluative criteria, and ways of } \\
\text { working }\end{array}$ \\
\hline $\begin{array}{l}\text { For Māori: } \\
\text { (for Indigenous) }\end{array}$ & $\begin{array}{l}\text { is about ensuring there are clear benefits for Māori from the } \\
\text { evaluation, and Māori aspirations are acknowledged within } \\
\text { the evaluation }\end{array}$ \\
\hline $\begin{array}{l}\text { With Māori: } \\
\text { (with Indigenous) }\end{array}$ & $\begin{array}{l}\text { is where Māori make up the majority of the evaluation team; } \\
\text { the evaluation is responsive to tribal and community contexts } \\
\text { and respectfully observes and utilizes te reo Māori me ngā } \\
\text { tikanga (Māori language and cultural practices) }\end{array}$ \\
\hline $\begin{array}{l}\text { As Māori: } \\
\text { (as Indigenous) }\end{array}$ & $\begin{array}{l}\text { is about evaluation that is guided, informed, and underpinned } \\
\text { by kaupapa tuku iho (cultural values gifted by ancestors) and } \\
\text { tikanga Māori (Māori cultural practices) }\end{array}$ \\
\hline $\begin{array}{l}\text { Role of non-Māori } \\
\text { (non-Indigenous) }\end{array}$ & $\begin{array}{l}\text { is where there is no automatic or assumed role for non-Māori } \\
\text { on the evaluation team and the participation of non-Māori } \\
\text { people is by invitation only }\end{array}$ \\
\hline
\end{tabular}


signed by the British Crown and rangatira (chiefs) in 1840. Tino Rangatiratanga has come to be understood as a translation for the term "self-determination" and refers to determination by Māori of issues that have an impact on Māori. Tino Rangatiratanga has been at the forefront of Māori aspirations since the signing of the treaty in 1840 and remains so today.

Kaupapa Māori evaluation also draws on Kaupapa Māori theory (Smith, 1997) and its use as a strategic and political tool to advance Māori aspirations and agendas. In Aotearoa, Kaupapa Māori theory is the touchstone for research and evaluation with Māori. Cram (2001) defines Kaupapa Māori as a Māori way, underpinned by Māori philosophies, values, and principles that have an aspirational orientation or vision for Māori cultural, social, and economic wellbeing.

At the same time, "By Māori, for Māori” emerged as part of the political and aspirational discourse of self-determination around Treaty of Waitangi claims and Kaupapa Māori theory. "By Māori, for Māori” was a cultural and political position that asserted the right of Māori to lead their own development, that is, be self-determining. Māori expectations in relation to the conduct of research and evaluation began to be reflected in Māori-specific ethical guidelines, such as those developed by the Health Research Council of New Zealand (2010) and by government agencies such as Te Puni Kōkiri (1999)_the Ministry for Māori Development-and the Ministry for Social Development (2004). However, the role and appropriateness of Pākehā ${ }^{1}$ researchers in research involving Māori was keenly debated. On the one hand, you had Māori arguing there was no place for Pākehā in Māori research (Walker, 1990). On the other hand Smith (1990) identified four culturally appropriate research models to address Māori research needs. These models ${ }^{2}$ of research were seen to have merit at the time, to mitigate the lack of Māori research capacity and capability (Cram, 1997).

Conducting evaluation within a Kaupapa Māori framework means that nonMāori evaluators undertake evaluation at the invitation of, and in partnership with, the Māori community (Mertens, 2009). For non-Māori evaluators, their participation in Kaupapa Māori evaluation is akin to the notion of guesthood (Harvey, 2003). From the outset, being a guest signifies acceptance of being on someone else's "turf" and a willingness to defer to the protocols of one's host. Within this context, guests understand that their role will be determined by Māori, and, ideally, they will have a heightened sense of awareness of their positionality and of being an "outsider" in the evaluation (Brayboy \& Deyhle, 2000).

So my definition of Indigenous evaluation has its roots in the struggle by Māori to be self-determining and to exercise control and decision making over their lives and the things that matter to Māori. Māori, however, are not alone in asserting a self-determination agenda. Indigenous people across the globe have long advocated for self-determination, and we see the importance of Indigenous self-determination reflected in Articles 3 and 4 of the United Nations Declaration on the Rights of Indigenous Peoples Resolution (adopted by the General Assembly on September 13, 2007) (see Table 2). 
Table 2. United Nations Declaration on the Rights of Indigenous Peoples: Articles 3 and 4

Article 3: Indigenous peoples have the right to self-determination. By virtue of that right they freely determine their political status and freely pursue their economic, social and cultural development.

Article 4: Indigenous peoples, in exercising their right to self-determination, have the right to autonomy or self-government in matters relating to their internal and local affairs, as well as ways and means for financing their autonomous functions.

\section{WHY INDIGENOUS-LED EVALUATION?}

Much has been written about the location of research and evaluation within Western traditions, including the dominance of this scholarship (Bishop, 2005; Smith, 1999; Wehipeihana \& McKegg, 2018); the role of imperialism, colonialism, and globalization in the elevation and privileging of Western research traditions (Chilisa, 2012; Cram, 2009); and research and evaluation as an exercise in power and political contestation for knowledge and resources (Bishop, 2005; Teariki, Spoonley, \& Tomoana, 1992; Te Awekotuku, 1991).

If evaluation is to make a positive difference in the lives of Indigenous peoples, and to the things that matter for Indigenous peoples, then the dominant Western discourse needs to be held at bay. Indigenous-led, Indigenous control is essential if Indigenous values, principles, and ways of working are to hold sway in Indigenous evaluation and for the creation of a safe space for Indigenous communities and evaluators to be Indigenous.

When an evaluation is led by Indigenous people, they are more likely to have the cultural capital for the following:

- to facilitate respectful engagement and the observance of cultural protocols; they know what matters to get relationships and the evaluation off to a good start (Durie, 2001);

- to utilize Indigenous knowledge, methods, and ways of working in an evaluation; they can provide a cultural "reading" or assessment of the cultural fit or appropriateness of data-collection methods and tools for Indigenous peoples (Goodwin, Sauni, \& Were, 2015);

- to facilitate understanding of what value and goodness look like through an Indigenous worldview; they can take the lead in sense making and analysis to ensure that the richness, subtlety, and nuance of meaning are not lost in translation and ensure the cultural validity of the evaluative conclusions drawn (Kirkhart, 2010).

When I listen to Indigenous speakers around the world, and I read the scant but growing indigenous evaluation literature, the "by" Indigenous or Indigenous-led 
criterion is not prominent, and Indigenous evaluation is conflated with culturally responsive methodologies. What this does, in my view, is to tacitly provide permission and/or by default suggest that it is "okay" for non-Indigenous evaluators to lead evaluation with Indigenous peoples.

In Aotearoa New Zealand, Māori aspirations for control over their own lives and for self-determination means that it is not okay for non-Māori to lead evaluation with whānau (extended family), hapū (clan or sub-tribe), iwi (tribe), or Māori organizations. However, this is not the norm outside of Aotearoa New Zealand. where non-Indigenous evaluators mostly lead evaluation projects with and in Indigenous communities. To a large extent, this stems from unquestioned assumptions by the international evaluation community that they can undertake high-quality evaluations when working in Indigenous communities, or crossculturally, where the culture, context, and language(s) are different from their own; collect good data; undertake culturally valid analysis; and make sound evaluative judgements (Wehipeihana, Davidson, McKegg, \& Shanker, 2010). There are increasing challenges to this assumption, but Indigenous evaluator numbers are small, with limited influence, and decision-making power is typically vested in non-Indigenous funders and evaluators.

My definition of Indigenous evaluation has Indigenous-led as a critical criterion, with no assumed or automatic role for non-Indigenous peoples, unless by invitation. It reflects my personal and professional belief about what it takes to conduct high-quality evaluation with Indigenous peoples. While many things can be learned in relation to cultural knowledge, some things can be known and revealed only from within the culture. For these reasons, "there is no substitute for the cultural capital (understanding, knowledge, and intuit) that comes from being of the culture" (Wehipeihana et al., 2010, p. 188).

\section{SUPPORTING INDIGENOUS-LED EVALUATION}

One of the arguments I hear most often is that there aren't enough Indigenous evaluators for evaluations with Indigenous peoples to be Indigenous-led. And I agree, so very simply more Indigenous evaluators are needed, and this needs to be a priority. Drawing on the Aotearoa New Zealand evaluation experience, some considerations for the Canadian Evaluation Society to support Indigenous-led evaluation include the following:

- $\quad$ supporting the development of Indigenous evaluators and Indigenous evaluation

- $\quad$ partnering with Indigenous people to guide evaluation

- $\quad$ increasing the cultural competence of non-Indigenous evaluators

- elevating Indigenous values and principles in the practice of evaluation in Canada

- understanding the importance of relationships when engaging with Indigenous peoples 
- advocating for the credibility and inclusion of Indigenous values, methods, and criteria.

\section{Supporting the Development of Indigenous Evaluators and Indig- enous Evaluation}

Community-based evaluation workshops, some explicitly targeting Māori, and funded through health-promotion and Māori development agencies have provided alternative pathways for Māori to enter the field of evaluation and for Māori to guide evaluation in their communities. Evaluation mentors, both Māori and non-Māori, have encouraged and supported Māori to complete tertiary evaluation qualifications.

The Aotearoa New Zealand Evaluation Association (ANZEA) has supported Māori (and Pacific) evaluators by providing and resourcing a dedicated convening space at its annual conference. Māori evaluators determine how this time is used and share how they have applied matauranga Mãori (Māori knowledge systems), te ao Māori (Māori perspectives and worldviews), and tribal knowledge and cultural protocols in their evaluation practice. This contributes to the building of Kaupapa Māori evaluation practice and principles and the strengthening of a Māori evaluation network.

In the development of the Aotearoa New Zealand evaluator competencies and evaluation standards, there was rich conversation and dialogue about what matters to evaluation in New Zealand, and what quality and goodness means. Māori evaluators decided that one way of expressing this was to do it on their own terms; this led to the formation of Ma te Rae (the Māori evaluation association) - the first Indigenous evaluation organization in the world. Ma te Rae actively participates in EVAL Indigenous, has its own programme of development work, and sits comfortably alongside ANZEA.

From a base of less than five in 1999, Māori evaluators numbered approximately 50 in $2018 .^{3}$

\section{Partnering with Indigenous People to Guide Evaluation}

Deep cultural knowledge is needed for evaluators to work safely and respectfully with Indigenous communities. This is not a skate-over-the-surface knowledge to get you in the door by observing a few cultural protocols. It is cultural knowledge that will help you respectfully navigate entry, agree on ways of working, including methods and approaches, and support Indigenous people to give expression to their views, values, and experiences.

Non-indigenous evaluators need to find an Indigenous community advisor or guide, such as a tribal Elder or community leader, to help guide evaluators and the evaluation. These cultural advisors provide historical and contextual information, connect evaluators to people in the community, and guide their observance of cultural protocols.

A word of caution: Even when you are Māori or Indigenous, you can't assume that your knowledge is applicable across all tribes and communities. 


\section{Increasing the Cultural Competence of Non-Indigenous Evaluators}

First, do your homework before engaging with or entering Indigenous communities. Find out about the history and current context (Ormond, Cram, \& Carter, 2006). Indigenous peoples get tired of telling and re-telling their history, their story. When you engage, after having done your homework, you display a genuine willingness and commitment to authentically engage with Indigenous people.

Second, look to expand your Indigenous networks. Start with people you know, and think broadly. It could be through the arts, sport, or a community project or organization. It may not be the specific Indigenous people you will engage with later, but you're building your "general" Indigenous cultural knowledge and understanding, which will help you in future engagements.

Third, undertake relevant professional development. This would include Indigenous-specific evaluation workshops as well as professional development in related fields, for example, culturally responsive evaluation, or workshops on equity, diversity, and combatting racism. You might also need to look to nonevaluation fields such as community development, social justice, the arts, or the environment-where they offer insights about working with Indigenous peoples, as well as Indigenous studies short courses or papers offered by tertiary education providers.

\section{Elevating Indigenous Values and Principles in the Practice of Evaluation in Canada}

In Aotearoa Maori, values and principles have been elevated in the practice of evaluation by the national association. ANZEA included the principles of the Treaty of Waitangi-partnership, protection, and participation-as part of its constitution. The inclusion of the Treaty principles establishes the uniqueness of evaluation in Aotearoa and focuses our evaluation leadership on what is needed to ensure the inclusion and participation of Indigenous peoples and Indigenous perspectives in all aspects of evaluation (Wehipeihana, Bailey, Davidson, \& McKegg, 2014). It also sends a clear message to organizations that fund evaluation about the centrality of Màori values and principles as integral to the practice of evaluation in Aotearoa. This was evident in the development of the New Zealand Evaluator Competencies and Evaluation Standards and the integration of Māori perspectives into these professional practice publications in Aotearoa.

\section{Understanding the Importance of Relationships when Engaging with Indigenous Peoples}

In Māori and Indigenous contexts, relationships are the glue, the anchor, and the currency for effective and respectful engagement (Wilson, 2008) - and for successful evaluations. It is through relationships that the evaluation process unfolds. And it is in relationships, and in doing things together, that relational trust is built. Relational trust paves the way for deeper and more meaningful connections. 
Relationships therefore are not something the evaluator simply pays attention to; they are inextricably linked to engaging with Indigenous people and therefore Indigenous evaluation (Wehipeihana et al., 2015).

\section{Advocate for the Credibility and Inclusion of Indigenous Values, Methods, and Criteria}

While there have been gains at a governmental level, which specifically require the use or consideration of Kaupapa Māori principles in evaluation involving Māori, significant challenges remain. The role of Māori as leaders, or as core members of evaluation teams, and the observance of cultural protocols are relatively well established. However, challenges remain in the determination of what counts as credible evidence, accepted methods, and the inclusion of Māori cultural values and principles in the framing of evaluative criteria.

Culturally grounded, national Māori health frameworks accepted and promoted by the New Zealand Ministry of Health (Ministry of Health, 2015-Te Whare Tapa Whà (The Four Cornerstones of Health) (Durie, 1994), Te Pae Mahutonga (Southern Cross Constellation-four elements of health promotion) (Durie, 1999), and Te Wheke (The Octopus-defining family health) (Pere, 1982)-have helped to elevate the importance of tikanga Māori (Māori cultural values) as critical to the assessment of Māori health outcomes. Furthermore, in 2019, there are positive indications of Māori values and principles being woven into national accountability frameworks for all New Zealanders, including Māori: "and that wellbeing considered from an Indigenous perspective moves the public policy discourse beyond Western constructs of wellbeing and enables an improved lived experience of wellbeing for everyone" (Te Puni Kōkiri \& Treasury, 2019, p. i).

The Indigenous Approaches to the Living Standards framework developed by Te Puni Kōkiri (the Ministry for Māori Development) and the Treasury, while having a focus on wellbeing for Māori specifically, articulates a way of looking at wellbeing that can be applied to the full range of populations within Aotearoa New Zealand (see Box 1). The framework offers a way of accounting for various values and beliefs that drive people's experiences of wellbeing and positions the New Zealand public sector to advance wellbeing in a different way, looking to respond to the various needs, interests, and aspirations of all New Zealanders (Te Puni Kōkiri \& Treasury, 2019).

\section{Box 1. An Indigenous approach to the living standards framework}

There is no one way to look at wellbeing. People view wellbeing differently depending on their values, beliefs and social norms. The way Māori view wellbeing is different from the way other New Zealanders view wellbeing. It is informed by te ao Māori (a Māori worldview) where, for example, whenua (land) is not seen just for its economic potential, but through 
familial and spiritual connections defined by cultural concepts such as whakapapa (genealogy) and kaitiakitanga (stewardship). A te ao Māori perspective of wellbeing is also informed by life experiences-similar to that of other indigenous populations across the globe-of significant disparity and inequitable access to the tools, resources and opportunities that form the foundation to wellbeing. Te Tiriti o Waitangi, Aotearoa New Zealand's founding document, puts significant weight on partnership, active protection of Māori interests and redress to address past wrongs-including ongoing disparity and inequity experienced by Māori and their ability to access and benefit from capital stocks in various forms. When taken together they convey an obligation on the Crown and Māori to work together. To do this, the Crown-Ministers, departments and other agencies-must seek to understand te ao Māori, particularly as it relates to improving the wellbeing of whānau now, and over generations to come. Fortunately, te ao Māori offers a way to consider wellbeing within a holistic, robust and long-standing system. (Te Puni Kōkiri \& Treasury, 2019)

Māori have long advocated that what's good for Māori is good for all New Zealanders, and the Indigenous Approaches to Living Standards framework is one example of culturally grounded, Indigenous principles and perspectives embedded within a national evaluative framework. The key message for evaluators is to promote and advocate for the inclusion of Indigenous values in evaluation with Indigenous peoples, and to argue the benefits for non-Indigenous peoples. It will also be important to persevere with these efforts because, based on the New Zealand experience, challenging and changing deep-seated values does not happen at pace, nor does it typically come about through all-encompassing, sweeping reform. In our experience, changing fundamental values comes about through uncompromising, incremental radicalism.

\section{A PARADIGM SHIFT IS NEEDED}

Non-Indigenous evaluators occupy a privileged position that has conferred the authority and power to define reality, to make impactful judgments about others, and for those judgements to be seen as accurate and valid (Johnson, 2001; Kirkhart, 2015; Sanakar, 2017). It can therefore be challenging for non-Indigenous evaluators to change their practice and to relinquish power and privilege. They have to want to do things differently or have a reason to see the world through alternative eyes. This may be for social justice reasons (Greene, 2011; Mertens, 2009), because of an ethic of care, or to do no harm, or they may be convinced by methodological or practice arguments such as multicultural validity (Kirkhart, 2010). Whatever their motivation, this is not simply about what they know and how they do evaluation; it is fundamentally about how they view the world-so a paradigm shift, or shifts will be needed. For example, this might include moving from ... 


\section{... evaluation as transactional to evaluation as relational}

Evaluation as transactional is about a focus on the processes of evaluation, the methods, tools, and timeframes needed to undertake an evaluation. Greene (2005) reminds us that evaluation is about not only what we do but also who we are and where we position ourselves in relation to others. The paradigm shift, therefore, to evaluation as relational recognizes that relationships are the primary currency of engagement for Indigenous peoples (Wehipeihana, 2013) and sees evaluation as inherently relational.

\section{... evaluator as expert to Indigenous people as experts}

Evaluator as expert acknowledges evaluators as having typically Western-framed evaluation qualifications, expertise, and experience (Wehipeihana \& McKegg, 2018). The paradigm shift to Indigenous peoples as expert affirms the unique cultural knowledge of Indigenous people to enter, navigate, and engage with their people (Durie, 2001; Smith, 1999) and demonstrates that the currency of Western knowledge and experience diminishes in Indigenous contexts (Wehipeihana, 2013).

\section{... evaluation as independent to evaluation as connected}

Evaluation as independent and non-biased is about the privileging of Western methods, or the imposition of relation boundaries providing validity and credibility in evaluative judgments. The paradigm shift to evaluation as connected affirms being Indigenous, of the community, and a known face (Cram, 2001; Smith, 1999 ) as central to the accuracy, credibility, and cultural validity of evaluative judgements (Wehipeihana \& McKegg, 2018).

\section{... evaluation managed by non-Indigenous evaluators to evaluation managed by Indigenous evaluators}

When evaluations in Indigenous communities are managed by non-Indigenous evaluators, Indigenous evaluators are not always present when key documents are developed and agreed and when significant decisions are made. Even when Indigenous evaluators are present, they are often out-numbered, junior in status, or in environments where there is no willingness or appetite to consider alternative options or views. So the underlying issue is one of power and control over decision making in evaluation (Wehipeihana et al., 2010). When evaluations are managed by Indigenous evaluators, they (mostly) get to decide what's important and therefore prioritized, how resources are allocated, the criteria for evaluative judgements, what counts as valid evidence, and how findings are reported.

\section{TOWARD INDIGENOUS CONTROL OF INDIGENOUS EVALUATION}

Implicit in all of the paradigm shifts is the ceding of control or, as a minimum, the sharing of power and authority with Indigenous peoples. I developed a model ${ }^{4}$ (Wehipeihana, 2013) to explore to what extent evaluators share power and decision making in evaluation with Indigenous peoples. 
Each aspect of the model is briefly discussed in Table 3. The model invites evaluators to reflect on their evaluation practice as a first step toward increasing decision making by Indigenous peoples in evaluation and with a clear goal of contributing to Indigenous-led evaluation. When applied as a self-assessment tool, it identifies how power is shared, and the extent to which Indigenous people have control over decision making in evaluation is made evident.

Some initial reflection questions were developed to support a self-assessment process:

- Who initiated the evaluation, and who benefits?

- What difference will it make for Indigenous peoples?

- Who will carry it out, and are they a good/appropriate "fit" for the community?

- How will the evaluation be carried out, and is the methodology a good/ appropriate "fit" for the community?

- What is (or will be) the role of the Indigenous people or communities in the evaluation? Is this role resourced? How do they feel about their role in the evaluation? Does it match their expectations? And if not, can it be changed?

- What are the opportunities for you or the evaluation to move up and along on the continuum?

- What needs to happen to support this movement?

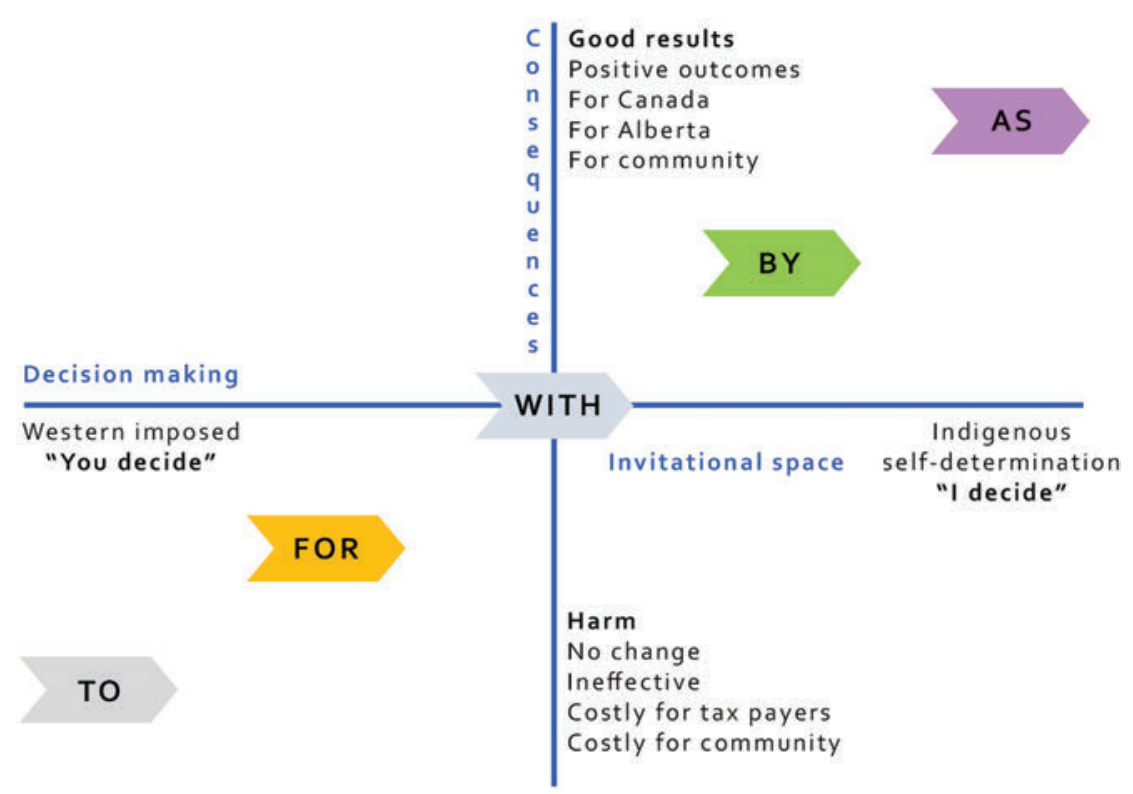

Figure 1. Wehipeihana Model 2013 
However, reflective questions-with an Indigenous interrogation lens-can be asked at any or every step of the evaluation process, from the commissioning of the evaluation (e.g., who initiated the evaluation and was the Indigenous community consulted?); managing the evaluation (e.g., who are the stakeholders, are Indigenous people represented, and are decision-making processes equitable?); the design of the evaluation (e.g., are Indigenous principles and methods included in the evaluation design and are Indigenous evaluators, and ideally local people, part of the evaluation team?); the analysis of the data (e.g., is there a process for checking the accuracy and cultural validity of data-analysis and evaluative conclusions?); and dissemination (e.g., how will the evaluation findings be shared with Indigenous communities?).

\section{CONCLUSION}

This paper has advocated for Indigenous-led as being central to Indigenous evaluation. It argues for personal paradigm shifts by non-Indigenous evaluators and funders of evaluation as necessary to disrupt their taken-for-granted assumptions of control and to radically shift the power balance by placing control in the hands of Indigenous peoples. Decolonizing one's evaluation practice is a deeply personal experience. It requires introspection, looking deeply at one's values and beliefs, soul searching, and surfacing and interrogating implicit assumptions and biases. It also requires humility, being open to other perspectives and worldviews, to recognize unearned privilege, and to share, and ultimately let go of, power. And it calls for

Table 3. Description of the Wehipeihana (2013) model elements

\begin{tabular}{|c|c|}
\hline $\begin{array}{l}\text { Decision } \\
\text { making }\end{array}$ & $\begin{array}{l}\text { The horizontal axis is a decision-making and control continuum } \\
\text { moving from Western control (you decide) through to Indigenous } \\
\text { control (I decide). }\end{array}$ \\
\hline Consequences & $\begin{array}{l}\text { The vertical axis is a consequences continuum moving from good } \\
\text { results and positive outcomes to no change, ineffective results, or } \\
\text { harm. }\end{array}$ \\
\hline $\begin{array}{l}\text { Evaluation } \\
\text { done to }\end{array}$ & $\begin{array}{l}\text { Indigenous peoples have no say or control over the evaluation } \\
\text { and there are no clear benefits for Indigenous peoples. Evaluation } \\
\text { is done to Indigenous peoples, and Western worldviews and } \\
\text { Western science prevail. }\end{array}$ \\
\hline $\begin{array}{l}\text { Evaluation } \\
\text { done for }\end{array}$ & $\begin{array}{l}\text { Seeks to improve the situation for Indigenous peoples but there is } \\
\text { minimal consultation with Indigenous peoples. The evaluation is } \\
\text { designed and managed without reference to Indigenous values, } \\
\text { principles, and priorities, and decision-making power resides with } \\
\text { the evaluator. Evaluation is paternalistic, and Western worldviews } \\
\text { and Western science prevail. }\end{array}$ \\
\hline $\begin{array}{l}\text { Evaluation } \\
\text { done with }\end{array}$ & $\begin{array}{l}\text { Power and decision making are shared and negotiated. It is a } \\
\text { collaborative and participatory space. Indigenous and Western } \\
\text { worldviews and approaches are utilized. }\end{array}$ \\
\hline
\end{tabular}


Table 3. Continued

\begin{tabular}{ll}
\hline $\begin{array}{l}\text { Evaluation } \\
\text { done by }\end{array}$ & $\begin{array}{l}\text { Indigenous people have control over the evaluation, and } \\
\text { Indigenous methods and worldviews prevail. Evaluations may } \\
\text { utilize Western methods. }\end{array}$ \\
$\begin{array}{l}\text { Evaluation } \\
\text { Indigenous peoples have control over the evaluation, and }\end{array}$ & $\begin{array}{l}\text { Indigenous knowledge and science are the norm. The legitimacy } \\
\text { and validity of Indigenous principles, values are taken for granted. } \\
\text { It does not exclude Western methods but includes them only as } \\
\text { far as they are seen to be useful. }\end{array}$ \\
& $\begin{array}{l}\text { The concept of the invitational space is where the evaluation is } \\
\text { controlled by Indigenous people, and non-Indigenous evaluators } \\
\text { Invitational } \\
\text { space }\end{array}$ \\
& accept that their participation is by invitation only. \\
\hline
\end{tabular}

courage, to embark on a journey that will be personally and professionally confronting, and tenacity, to stay the course and stand up to cynics, critics, and racists. It's an important first step.

At the same time, there is a need to confront institutional and structural barriers by supporting the development of Indigenous evaluators and an Indigenous evaluation community; elevating Indigenous values and principles in Canadian evaluation practice; advocating for the credibility and inclusion of Indigenous values, methods, and criteria within evaluation; and building the cultural competency of non-Indigenous evaluators and funders of evaluation.

\section{NOTES}

1 New Zealanders of European descent.

2 The Tiaki (Mentor) model, where research is guided by authoritative Māori; the Whangai (Adoption) model, where researchers become one of the whänau; the Power Sharing model, where the researcher and community jointly engage in the research; and the Empowering Outcomes model, where researchers provide information and answers to questions or topics that Māori want to find out about.

3 Evaluators who identify as Māori on the Ma te Rae Māori evaluation association membership list as of November 2018.

4 The model was initially titled "A framework for increasing control by Indigenous communities" for the AES 2013 Conference Wehipeihana (2013). Soon after (and also in 2013) I referred to it as "Locating evaluation pactice: evaluation as an expression of power, control, and consequences." For the CES 2018 keynote presentation, I referred to it as "A framework for assessing evaluator progress towards Indigenous cultural competency and Indigenous-led evaluation." I tend to change the title to convey a key message or purpose to suit the audience or context.

\section{REFERENCES}

Bishop, R. (2005). Freeing ourselves from neocolonial domination in research: A Kaupapa Maori approach to creating knowlege. In N. Denzin \& Y. Lincoln (Eds.), The SAGE handbook of qualitative research (3rd ed., pp. 109-138). Thousand Oaks, CA: SAGE. 
Brayboy, B. M., \& Deyhle, D. (2000). Insider-outsider: Researchers in American Indian communities. Theory into Practice, 39(3), 163-169. https://doi.org/10.1207/s15430421 tip3903_7

Chilisa, B. (2012). Indigenous research methodologies. Los Angeles, CA: SAGE.

Cram, F. (1997). Developing partnerships in research: Pākehā researchers and Māori research. SITES, 35, 44-63.

Cram, F. (2001). Rangahau Maori: Tona Tika, Tona Pono-The validity and integrity of Māori. In M. Tolich (Ed.), Research ethics in Aotearoa New Zealand (pp. 35-52). Auckland, New Zealand: Pearson Education.

Cram, F. (2009). Maintaining indigenous voices. In D. Mertens \& P. Ginsberg (Eds.), The SAGE handbook of social science research ethics (pp. 308-322). Thousand Oaks, CA: SAGE.

Cram, F. (2016). Lessons on decolonizing evaluation from Kaupapa Māori evaluation. Canadian Journal of Program Evaluation, 30(3), 296-312. https://doi.org/10.3138/ cjpe.30.3.04

Cram, F., Chilisa, B., \& Mertens, D. M. (2013). The journey begins. In D. M. Mertens, F. Cram, \& B. Chilisa (Eds.), Indigenous pathways into social research: Voices of a new generation (pp. 11-40). Walnut Creek, CA: Left Coast Press.

Durie, M. (1994). Whaiora: Māori health development. Auckland: Oxford University Press.

Durie, M. (1999, December). Te Pae Mahutonga: A model for Māori health promotion. Health Promotion Forum of New Zealand Newsletter, 49, 2-5.

Durie, M. (2001). A framework for considering Māori educational advancement: The Hui Taumata Matauranga. Taupo, New Zealand: Massey University.

Goodwin, D., Sauni, P., \& Were, L. (2015). Cultural fit: An important criterion for effective interventions and evaluation work. Evaluation Matters-He Take Tō Te Aromatawai, 1, 25-46. https://doi.org/10.18296/em.0003

Greene, J. C. (2005). Evaluators as stewards of the public good. In S. Hood, H. Frierson, \& R. Hopson (Eds.), The role of culture and cultural context in evaluation: A mandate for inclusion, the discovery of truth and understanding (pp. 7-20). Charoltte, NC: Information Age Publishing.

Greene, J. C. (2011). Evaluation and the public good: A mixed methods perspective. Paper presented at the Aotearoa New Zealand Evaluation Association Conference, Wellington, New Zealand.

Harvey, G. (2003). Guesthood as ethical decolonising research method. Numen: International Review for the History of Religions, 50(2), 125-146. https://doi.org/10.1163/ 156852703321506132

Health Research Council of New Zealand. (2010). Guidelines for research on health research involving Māori. Retrieved from http://www.hrc.govt.nz/news-and-publications/publications/guidelines-researchers-health-research-involving-m\%C4\%81ori

Henare, M. (1988). Ngā Tikanga Me Ngā Ritenga O Te Ao Māori. Standards and foundations of Māori society. In The April report: Report of the Royal Commission on Social Policy Future; Directions. Vol 3, part 1: Future directions, associated papers (pp. 3-42). Wellington, New Zealand: The Royal Commission on Social Policy. 
Johnson, A. (2001). Privilege, power and difference. Mountain View, CA: Mayfield.

Kirkhart, K. E. (2010). Eyes on the prize: Multicultural validity and evaluation theory. American Journal of Evaluation, 31(3), 400-413. https://doi.org/10.1177/1098214010373645

Kirkhart, K. E. (2015). Unpacking the evaluator's toolbox: Observations on evaluation, privilege, equity and justice. Evaluation Matters-He Take Tō Te Aromatawai, 1, 7-24. https://doi.org/10.18296/em.0002

LaFrance, J., \& Nichols, R. (2010). Reframing evaluation: Defining an indigenous evaluation framework. Canadian Journal of Program Evaluation, 23(2), 13-31.

Marsden, M., \& Royal, T. A. C. (2003). The woven universe: Selected writings of Rev. Māori Marsden. N.p.: Estate of Rev. Māori Marsden.

Mertens, D. M. (2009). Transformative research and evaluation. New York, NY: Guilford Press.

Ministry of Health. (2015). Māori health models. Retrieved from https://www.health.govt. nz/our-work/populations/maori-health/maori-health-models

Ministry for Social Development. (2004). Ngā Ara Tohutohu Rangahau Māori-Guidelines for Research and Evaluation with Mäori. Centre for Social Research and Evaluation Te Pokapü Rangahau Arotake Hapori. Wellington, New Zealand: Minstry for Social Development.

Ormond, A., Cram, F., \& Carter, L. (2006). Researching our relations: Reflections on ethics. Alternative: An International Journal of Indigenous Scholarship, Special supplement 2006-Marginalisation, 180-198.

Pere, R. (1982). Ako: Concepts and Learning in the Maori tradition. Hamilton, New Zealand: University of Waikato Press.

Sanakar, M. (2017). A stocktake on culturally responsive evaluation in and outside the UN system. A discussion document prepared for UNEG Strategic Objective 3: Evaluation informs UN system-wide initiatives and emerging demands. United Nations Evaluation Group, UNESCO Evaluation Office.

Smith, G. H. (1990). Research issues related to Mäori education. Paper presented at the NZARE Special Interests Conference.

Smith, G. H. (1997). The development of Kaupapa Māori: Theory and praxis (Unpublished doctoral thesis). University of Auckland, Auckland, New Zealand.

Smith, L. T. (1999). Decolonising methodologies: Research and Indigenous peoples. Dunedin, New Zealand: University of Otago Press.

Spiller, C., \& Stockdale, M. (2013). Managing and leading from a Māori perspective: Bringing new life and energy to organisations. In J. Neal (Ed.), Handbook of faith and spirituality in the workplace: Emerging research and practice (pp. 149-173). New York, NY: Springer. https://doi.org/10.1007/978-1-4614-5233-1_11

Teariki, C., Spoonley, P., \& Tomoana, N. (1992). Te Whakapakari te Mana Tangata: The Politics and Process of Research for Māori. Palmerston North, New Zealand: Massey University.

Te Awekotuku, N. (1991). He tikanga whakaaro: Research ethics in Māori community. A discussion paper. Wellington, New Zealand. 
Te Puni Kōkiri. (1999). Evaluation for Māori: Guidelines for government agencies. Aroturuki me te Arotakenga Monitoring and Evaluation Branch. Wellington, New Zealand: Te Puni Kōkiri.

Te Puni Kōkiri and Treasury. (2019). An Indigenous approach to the living standards framework. The Treasury Discussion Paper 19/01. Wellington, New Zealand: Treasury.

Walker, H. (1990). Māori attitudes on research. Wellington, New Zealand: Department of Social Welfare

Wehipeihana, N. (2013). A vision for Indigenous evaluation. Keynote paper presented at the Australasian Evaluation Society Conference.

Wehipeihana, N., Bailey, R., Davidson, E. J., \& McKegg, K. (2014). Evaluator competencies: The Aotearoa New Zealand experience. Canadian Journal of Program Evaluation, 28(3), 49-69.

Wehipeihana, N., Davidson, E. J., McKegg, K., \& Shanker, V. (2010). What does it take to do evaluation in communities and cultural contexts other than our own? Journal of MultiDisciplinary Evaluation, 6(13), 182-192.

Wehipeihana, N., \& McKegg, K. (2018). Values and culture in evaluative thinking: Insights from Aotearoa New Zealand. New Directions for Evaluation, 158, 93-107. https://doi. org/10.1002/ev.20320

Wehipeihana, N., McKegg, K., Thompson, V., \& Pipi, K. (2015). Cultural responsiveness through developmental evaluation: Indigenous innovations in sport and traditional Māori recreation. In M. Q. Patton, K. McKegg, \& N. Wehipeihana (Eds.), Developmental evaluation exemplars: Principles in practice (pp. 25-44). New York, NY: Guilford Press.

Wilson, S. (2008). Research is ceremony: Indigenous research methods. Black Point, NS: Fernwood.

\section{AUTHOR INFORMATION}

Nan Wehipeihana Nan is an independent evaluation consultant, based in Wellington New Zealand. Nan has more than 20 years evaluation experience and specializes in evaluation and research with a focus on Māori (the Indigenous people of New Zealand). Nan established Research Evaluation Consultancy in 1997 and is a member of the Kinnect Group. Nan is a former board member of the Aotearoa New Zealand Evaluation Association (ANZEA) and a former appointed executive member of the Australasian Evaluation Society (AES). Nan's iwi (tribal) affiliations are to Ngāti Porou and Te Whānau-ā-Apanui on the East Coast of New Zealand and Ngāti Tukorehe and Ngāti Raukawa, north of Wellington, New Zealand. 